\title{
SÓ À DISTÂNCIA MOSTRA-SE OS DENTES
}

Hortência Abreu

Ricardo Burgarelli

A instalação Só à distância mostra-se os dentes é fruto de uma pesquisa artística sobre o imaginário do conflito conhecido como a Guerra do Paraguai. Nela buscamos dar visibilidade para asactos pouco con engloban una especie de náo dito da historiografia brasileira, já que, em outros paises latino-americanos, ha uma crítica efetiv sobre o posicionamento do Brasil no conflito. Propomos um atualização do episódio a partir das imagens geradas sobre o conflito e que se relaciona com contextos políticos e socioeconômicos adjacentes. Nosso objetivo é reatualizar um imaginário sobre a guerra tecido a contrapelo do posicionamento político do estado brasileiro em relação às narrativas da guerra, em cuja historiografia predomina o ocultamento de seu papel na deva tacão do Paraguai. E de nosso interesse dar a penção ao poder simbólico da representação trazer para o cento das reflexós simbólico da representaçao e trazer para o centro das reflexoes de africanos escravizados, alistados compulsoriamente durante a guerra e crianças paraguaias obrigadas a participar de combates. Ao mesmo tempo, ao resgatar a importância dos jornais confec-

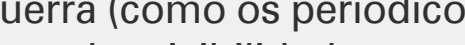
Cabichuí e Cacique Lambarel, procuramos dar visibilidade a uma narrativa escrita pelos paraguaios que foi sistematicamente ocultada aos brasileiros por uma narrativa de vencedores. Através da inclusão de figuras indígenas e da língua guarani, os jornais paraguaios escritos durante a guerra também contribuem para colocar em cena referências simbólicas desprezadas pela historiografia nacional brasileira, além de problematizar a quase inexistência de falantes da língua guarani em solo brasileiro. O tema da língua torna-se central, apontando para dizimação das populações indígenas que ainda oconr indigenas que anda ocorre no Brasil e para a fragilidade a que foi exposta uma memória construída através da oralidade. Por ou-
tro lado, a presença dos negros escravizados, coloca em debate 
questoes que reverberam até hoje na marginalidade da população negra brasileira, traço colonialista perpetuado e exercido pelo indígenas e os paraguaios.

Hortência Abreu e Ricardo Burgarelli têm graduação e mestrado em Artes Visuais pela Universidade Federal de Minas Gerais. Fazem parte do coletivo Vão, que desenvolve um trabalho artístico (intervenções públicas e publicações) e também produz eventos culturais como feiras e exposições na cidade de Belo Horizonte. Desde 2015 vêm realizando uma pesquisa artística sobre a Guerra Desde 2015 vêm realizando uma pesquisa artística sobre a Guerra
contra o Paraguai, a partir da qual constituíram a proposta de inscontra o Paraguai, a partir da qual constituíram a proposta de ins-
talação Só à distância mostra-se os dentes. Em 2016, apresenta-

ram um dossiê homônimo no seminário $O$ que resta da ditadura. a arte latino-americana em tempos de crise, na Escola de Belas Artes, UFMG, expondo os desdobramentos teóricos e práticos de sua pesquisa coletiva. 







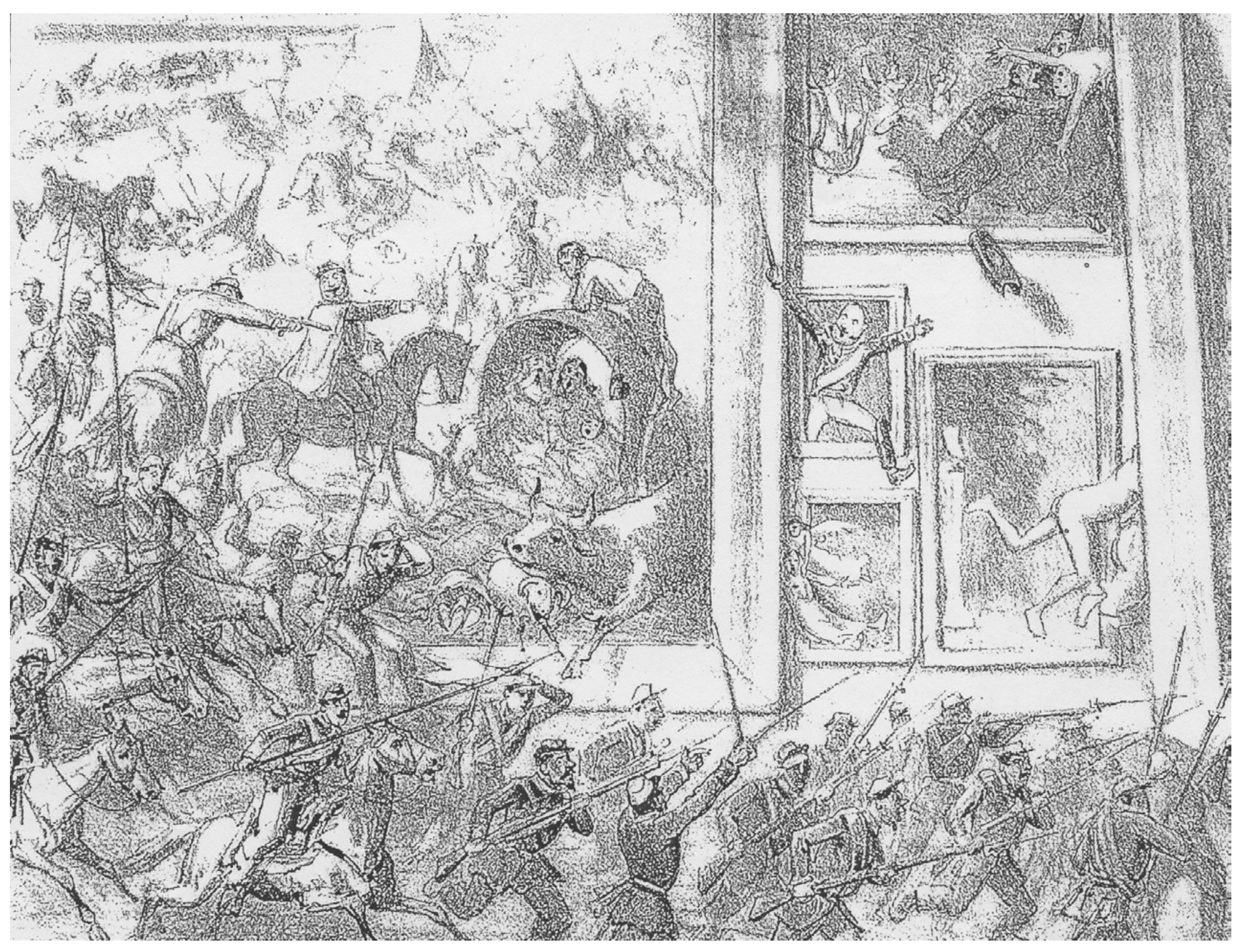




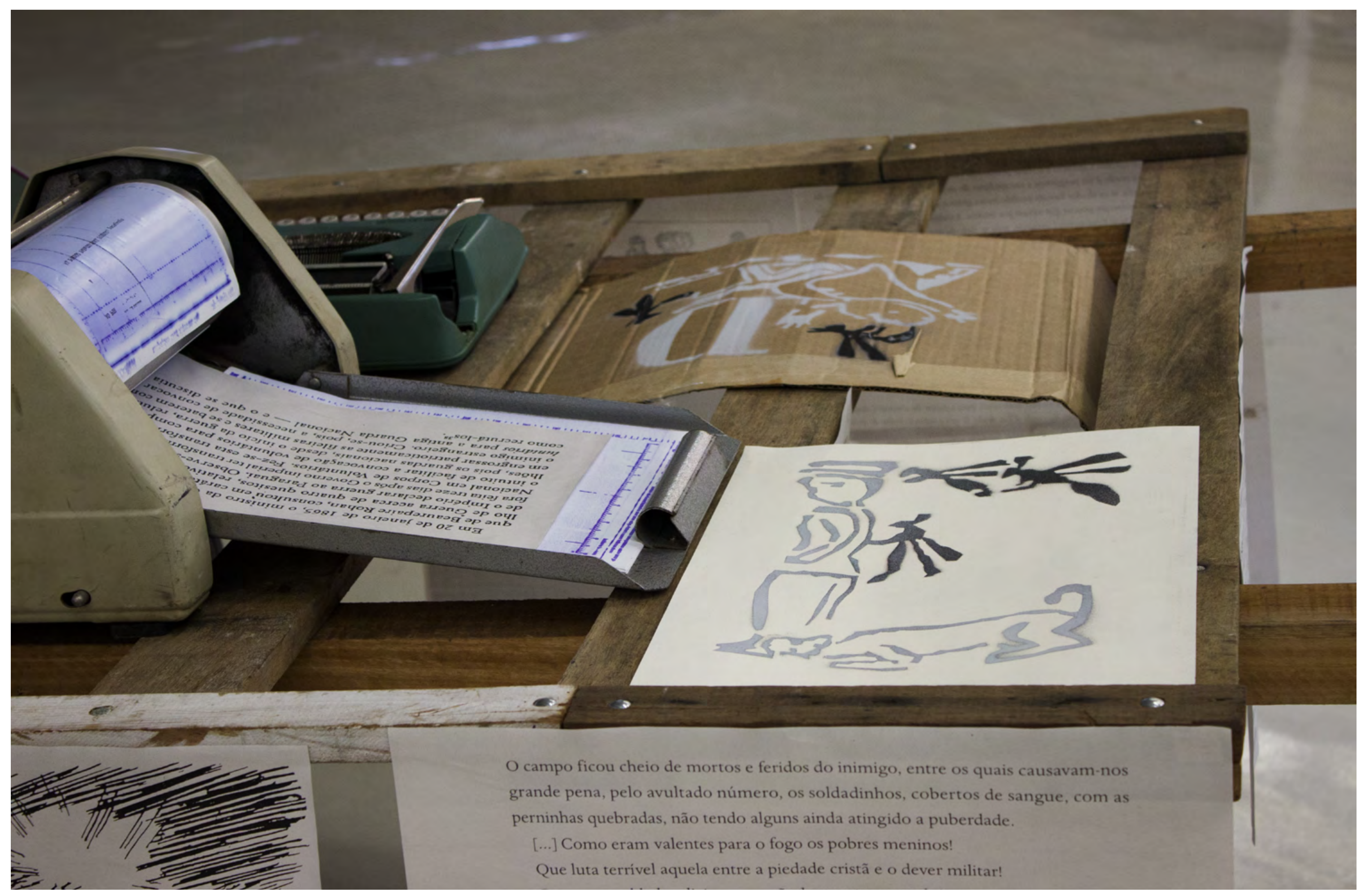




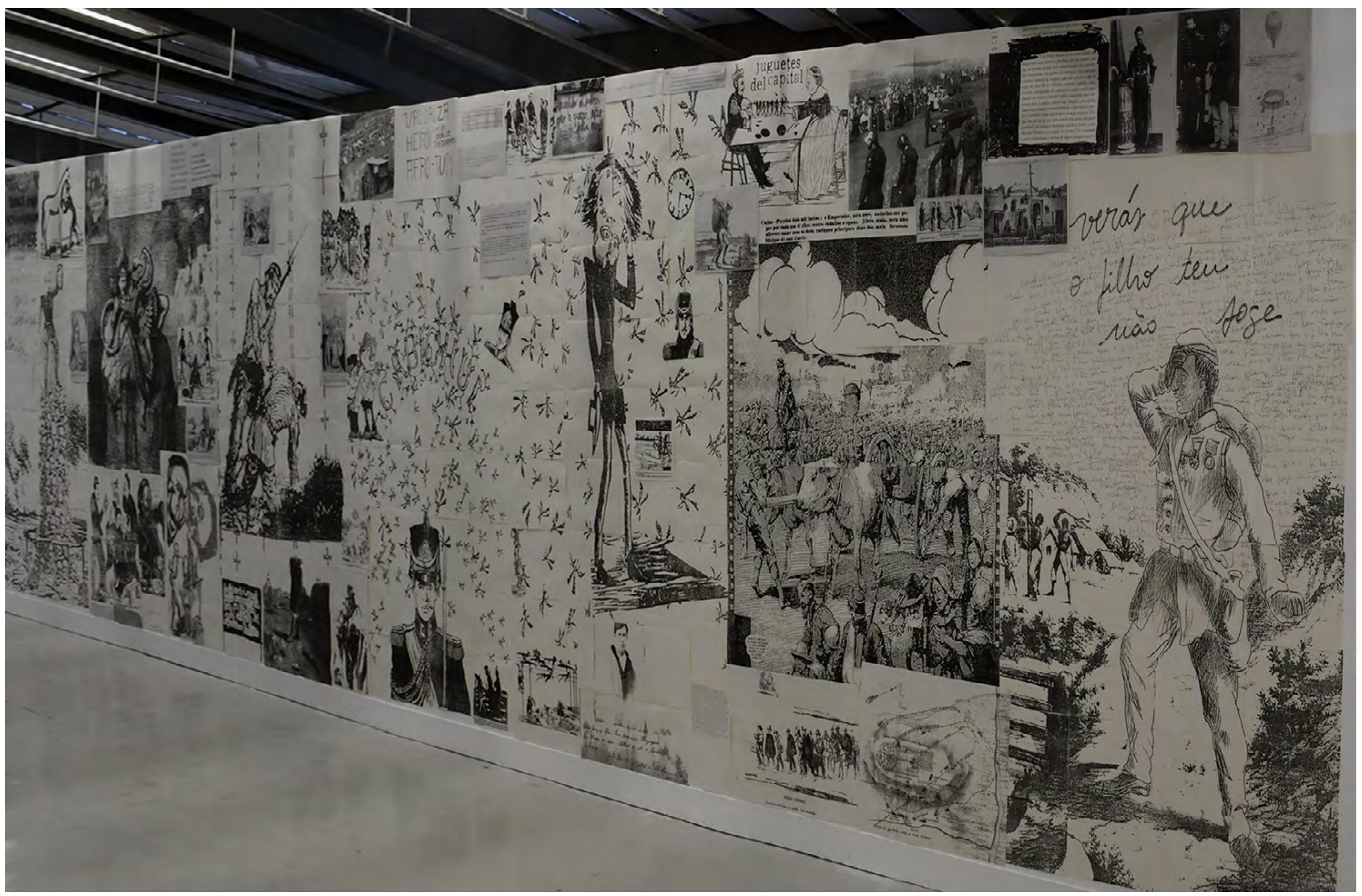




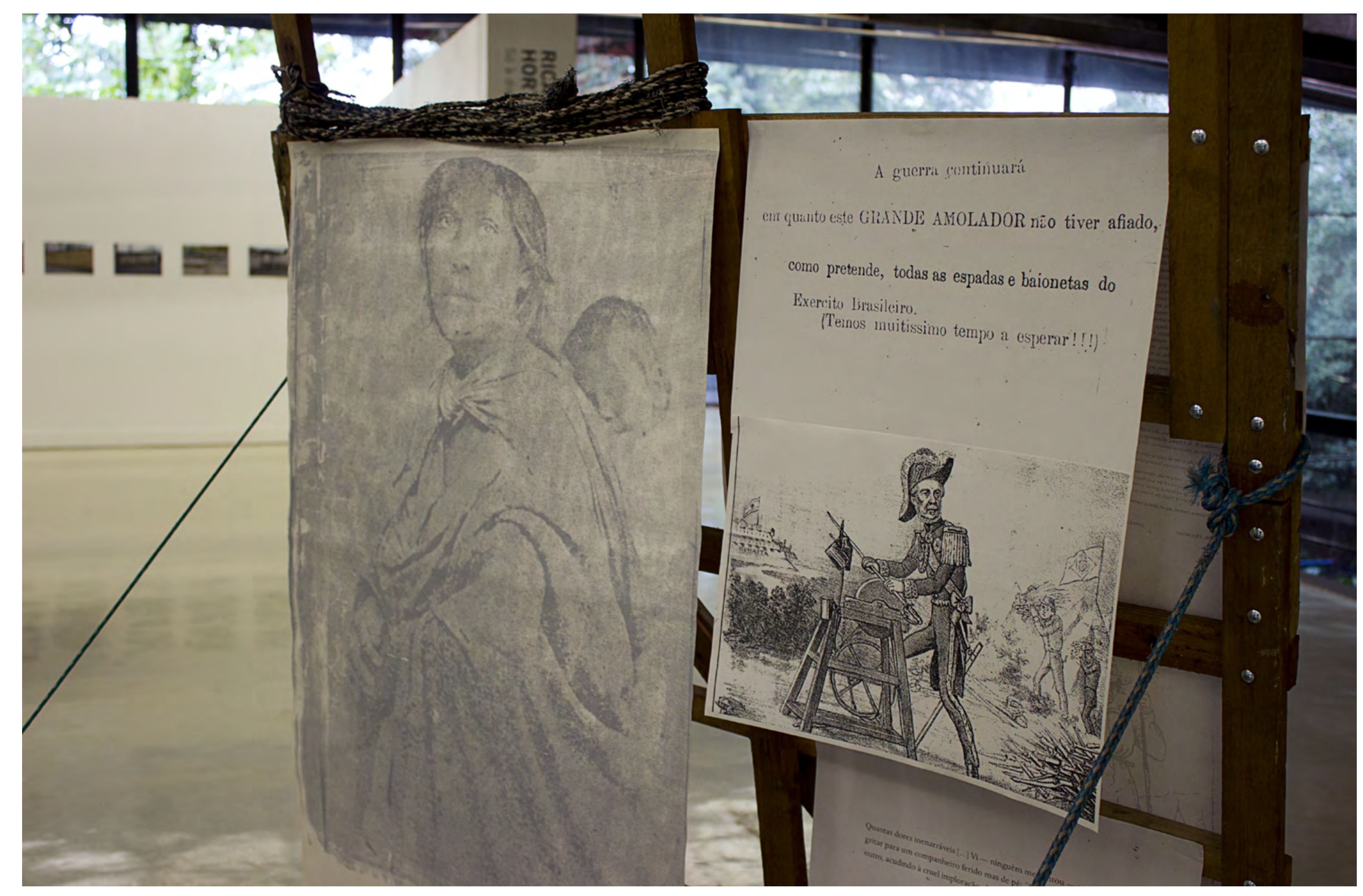




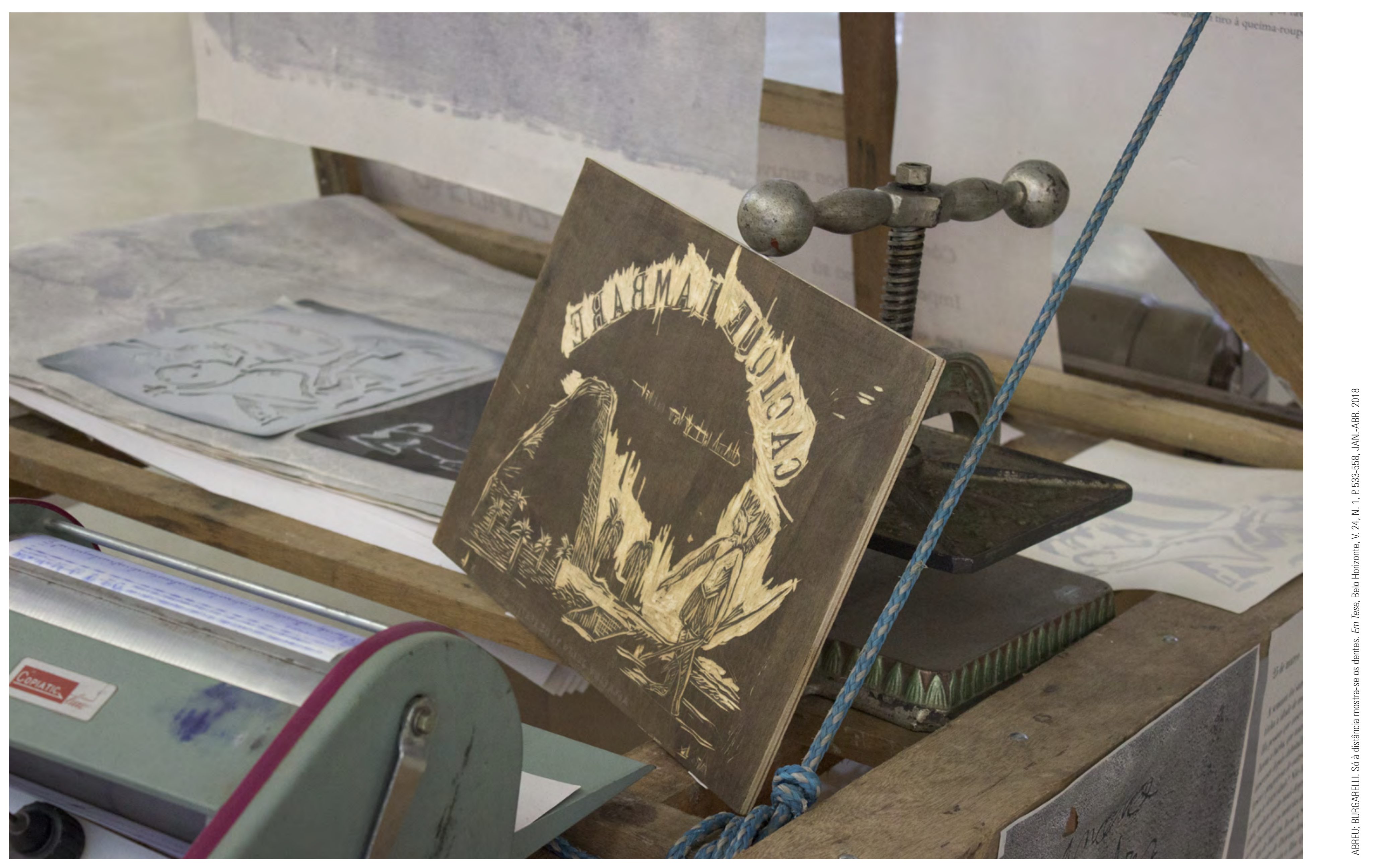




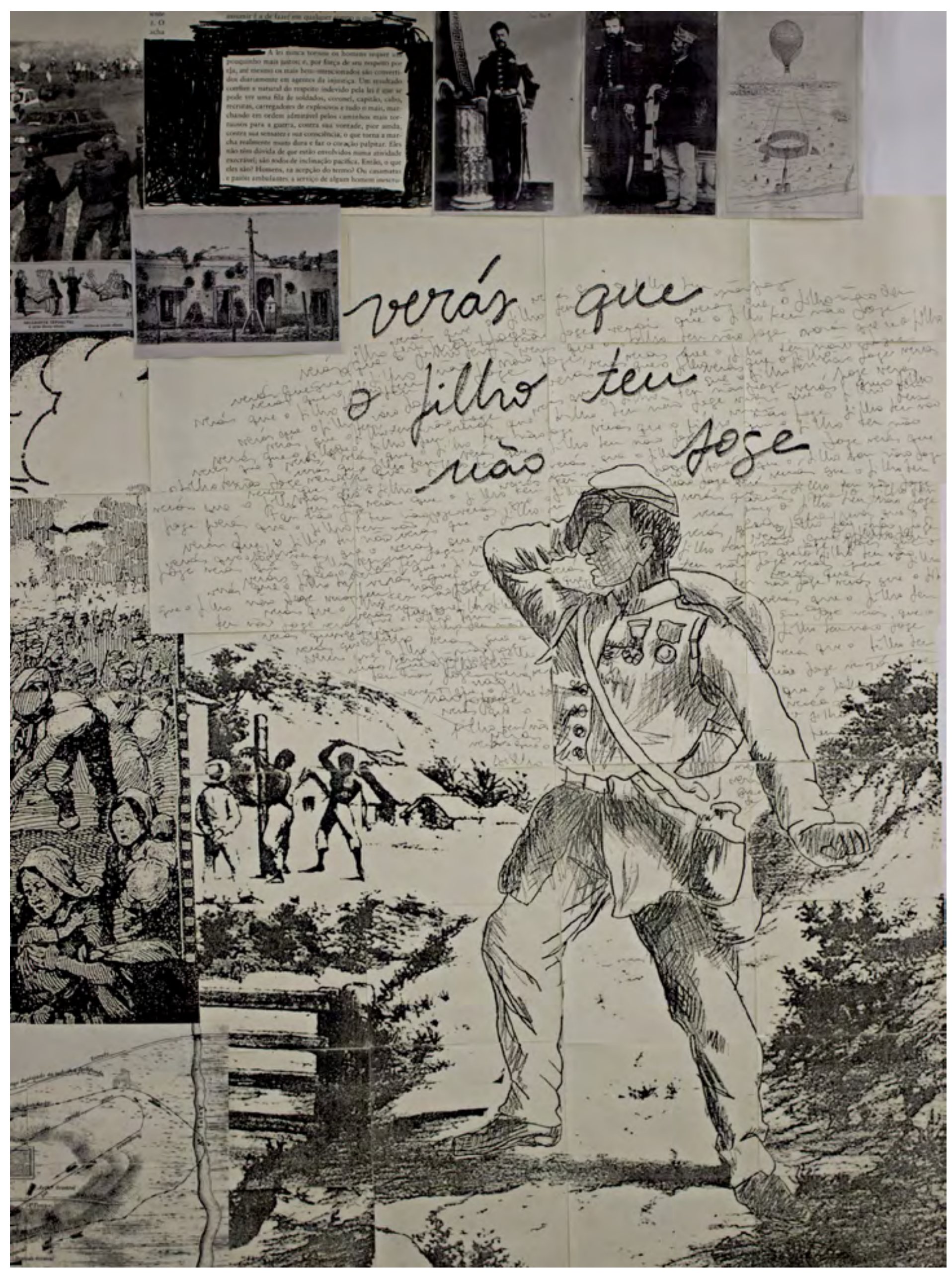




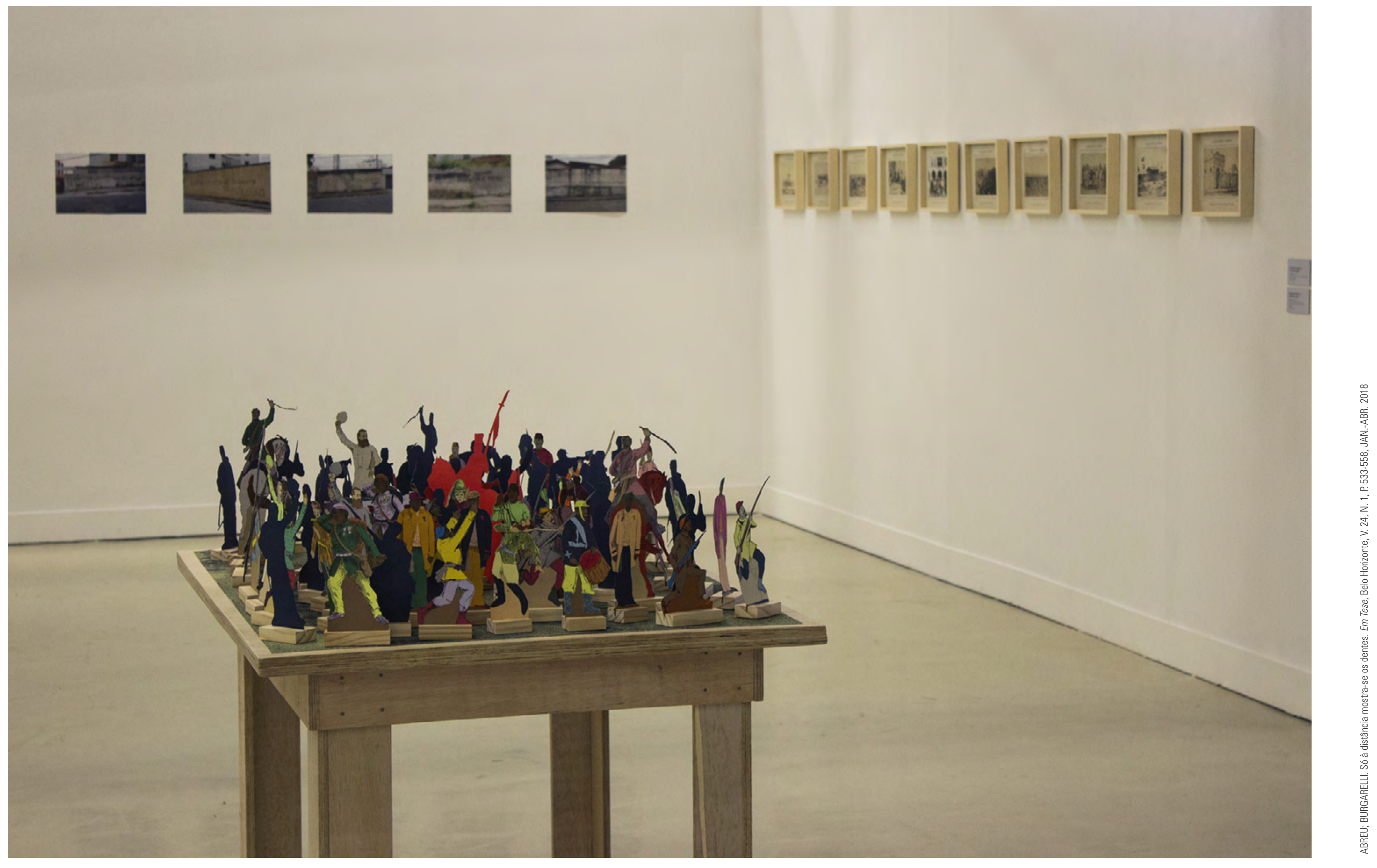




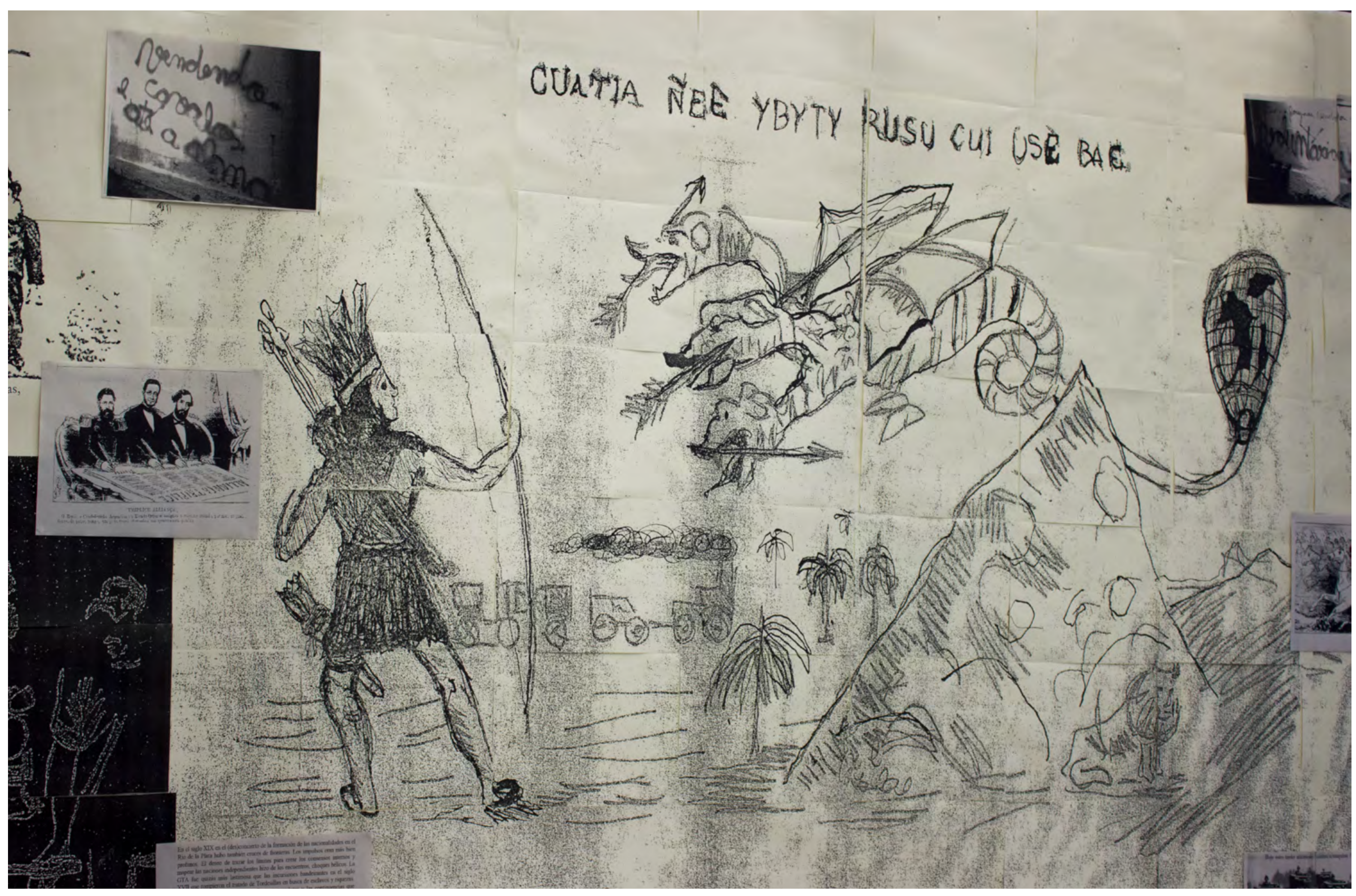




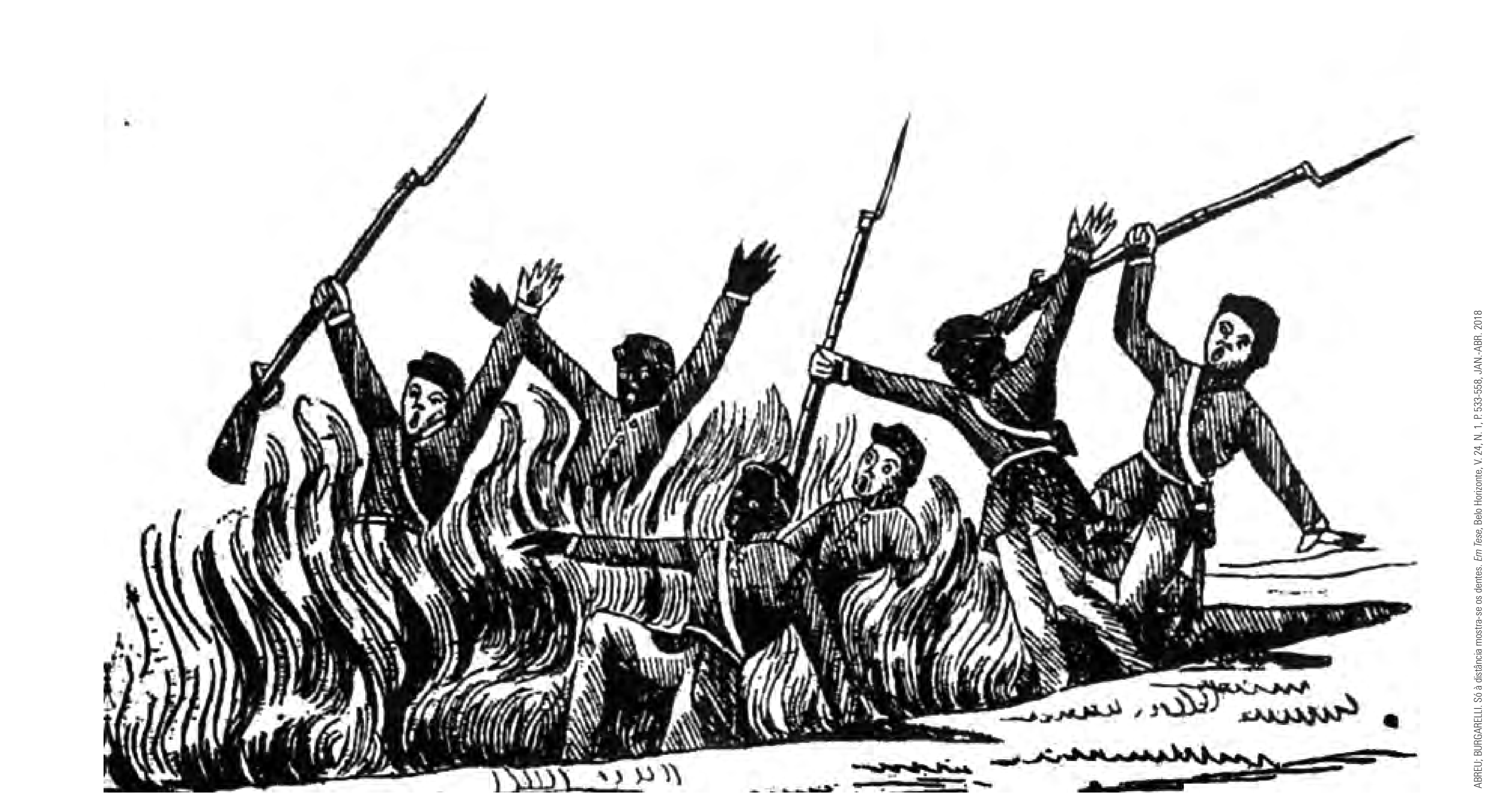









\section{LA GUERRA CONTRA EL PARAGUAY}

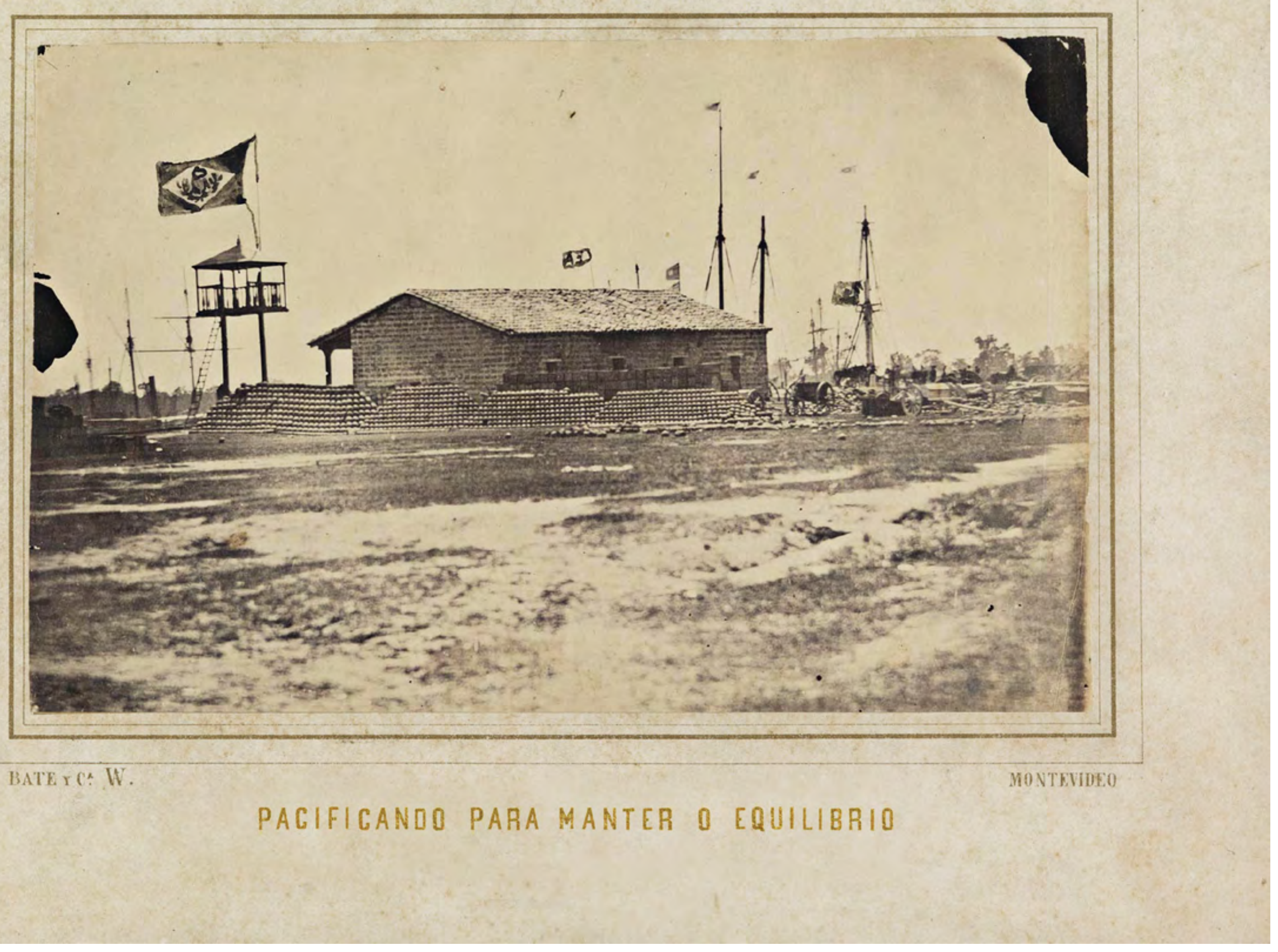




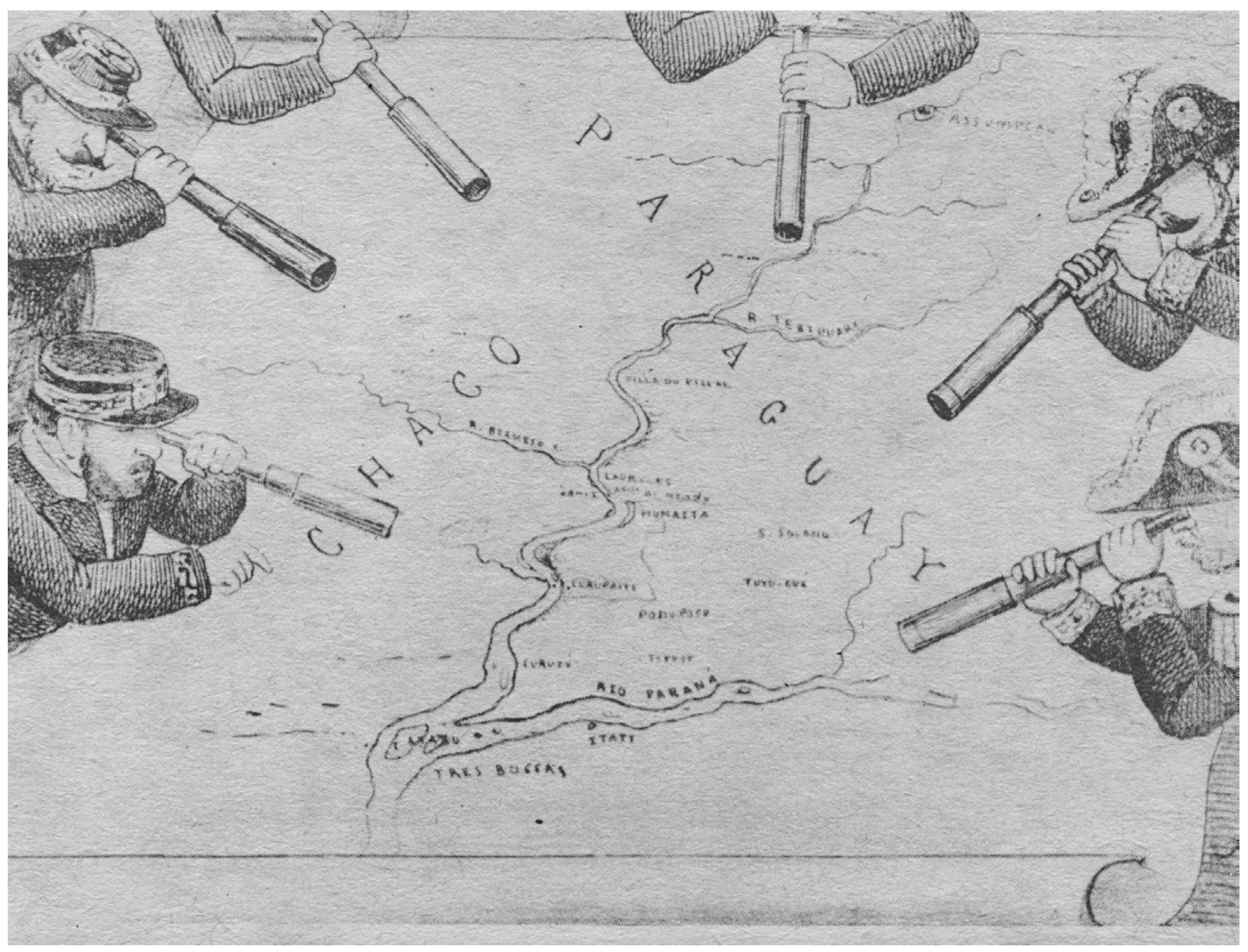




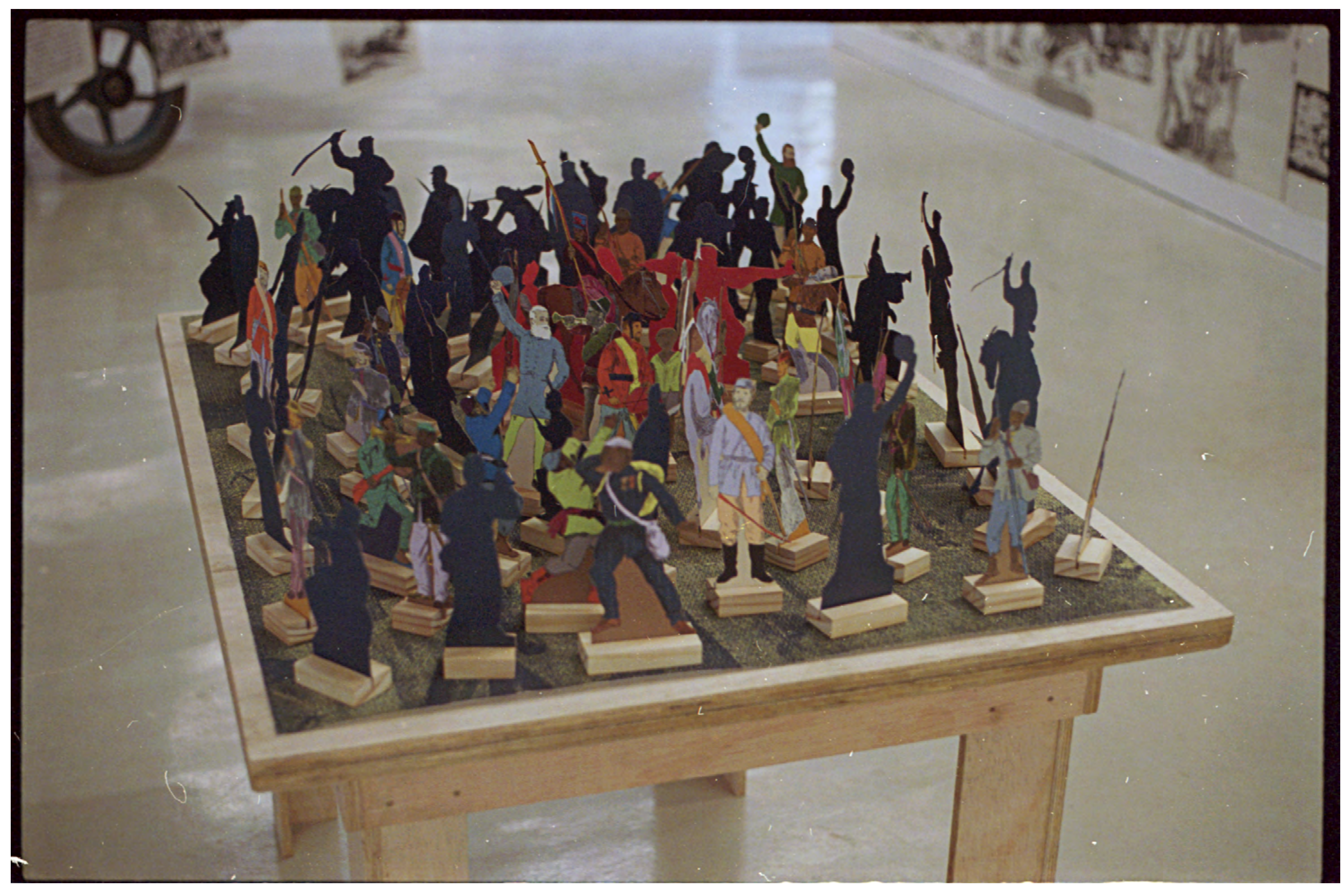




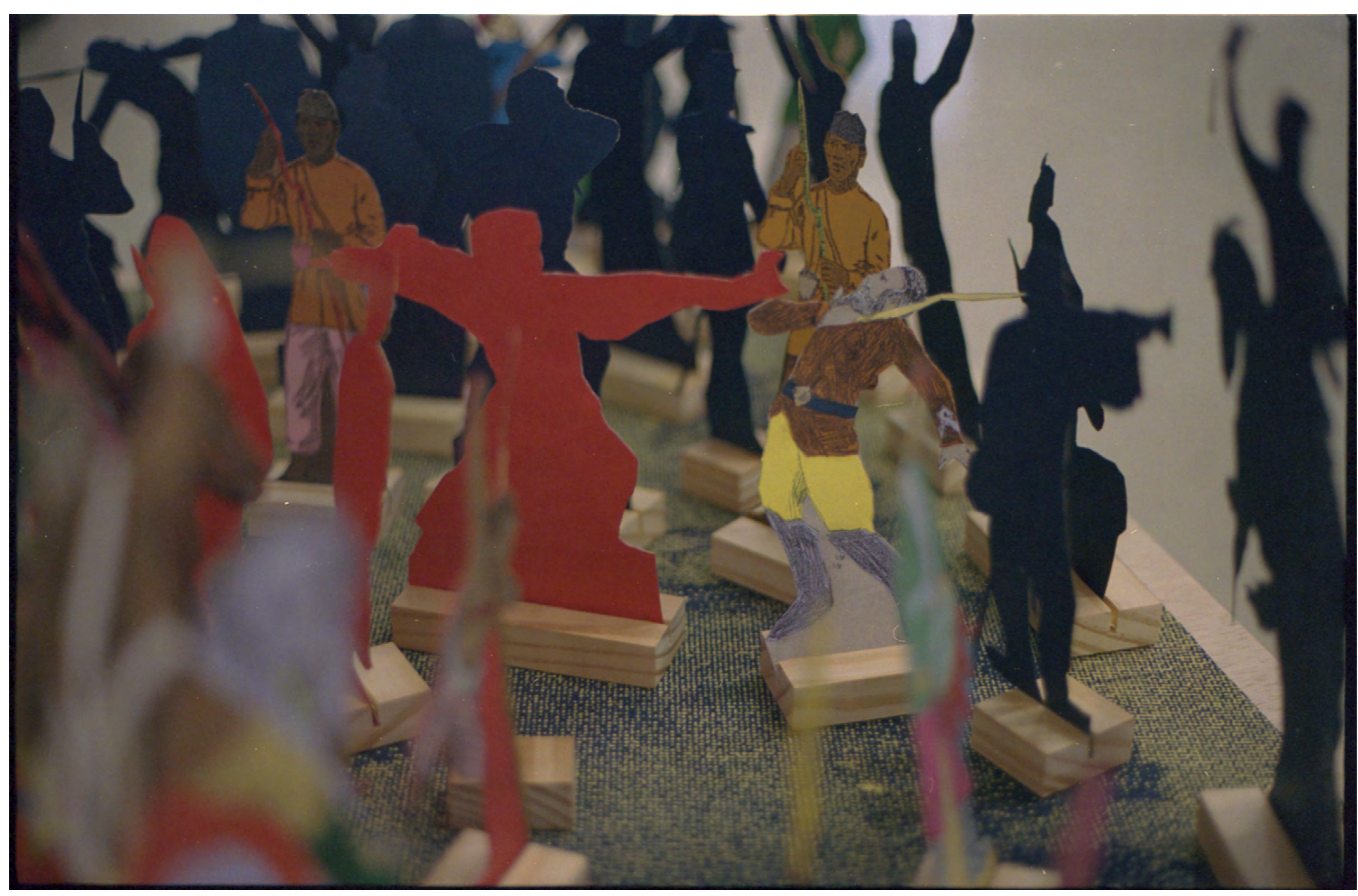




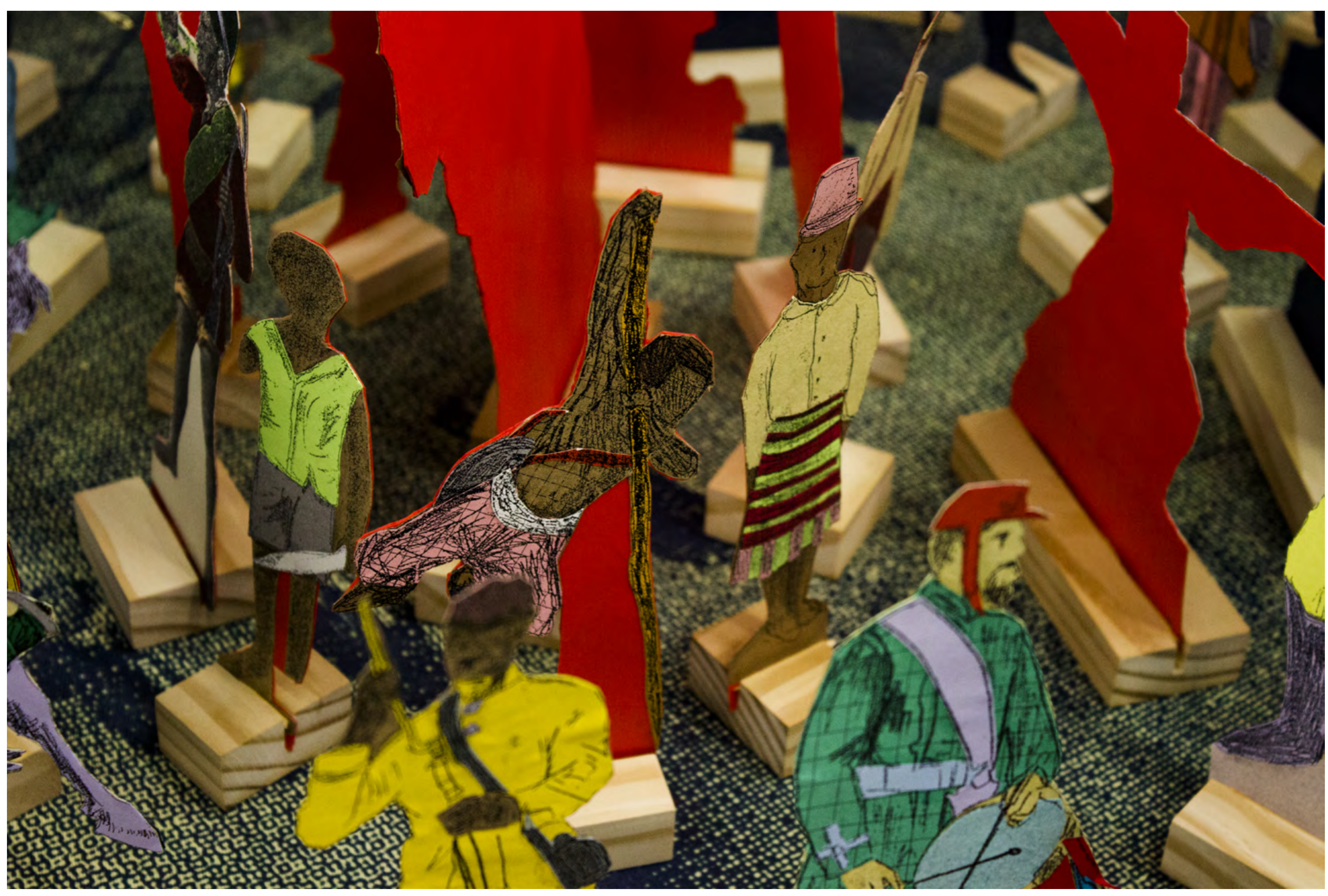




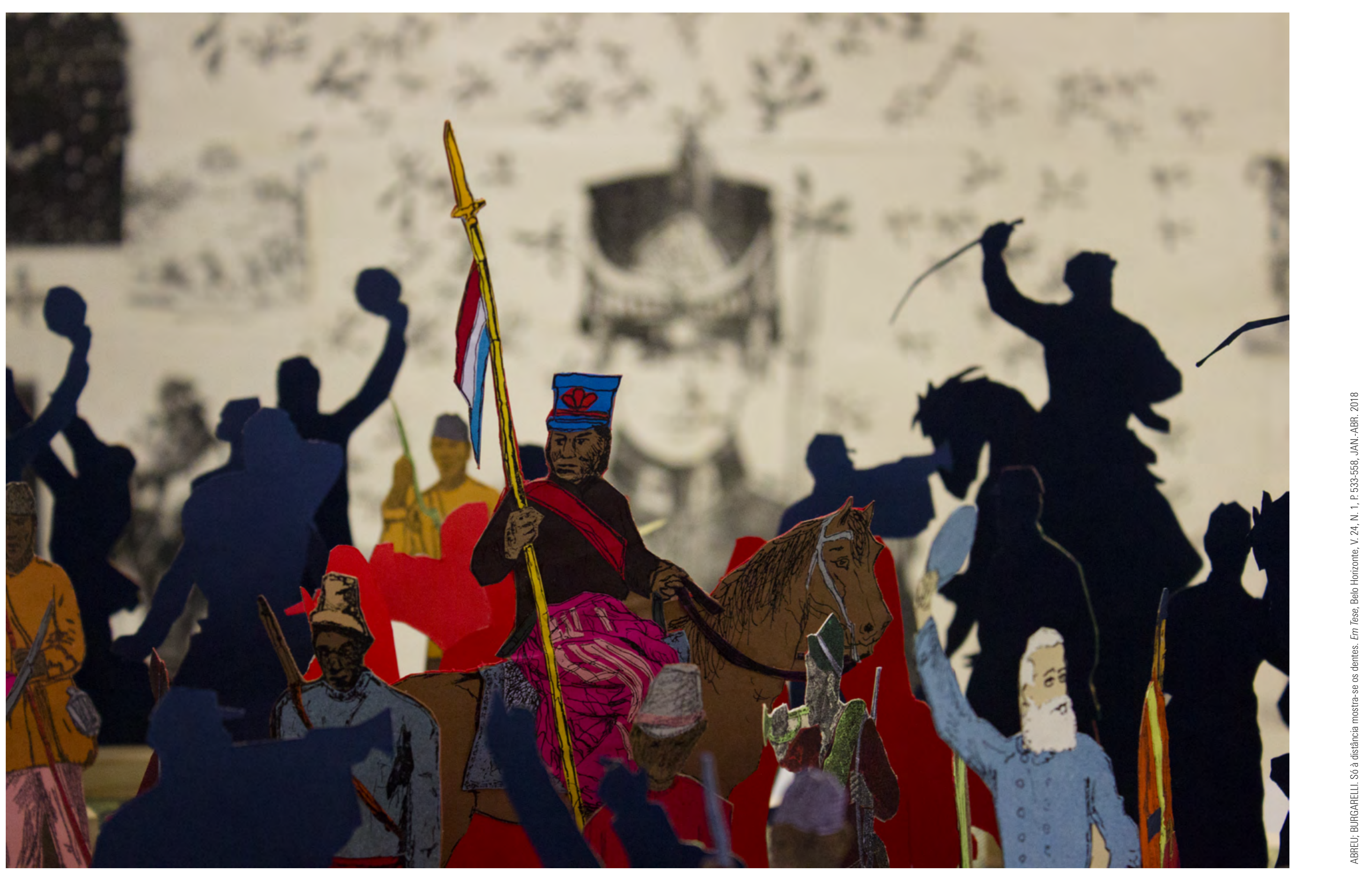




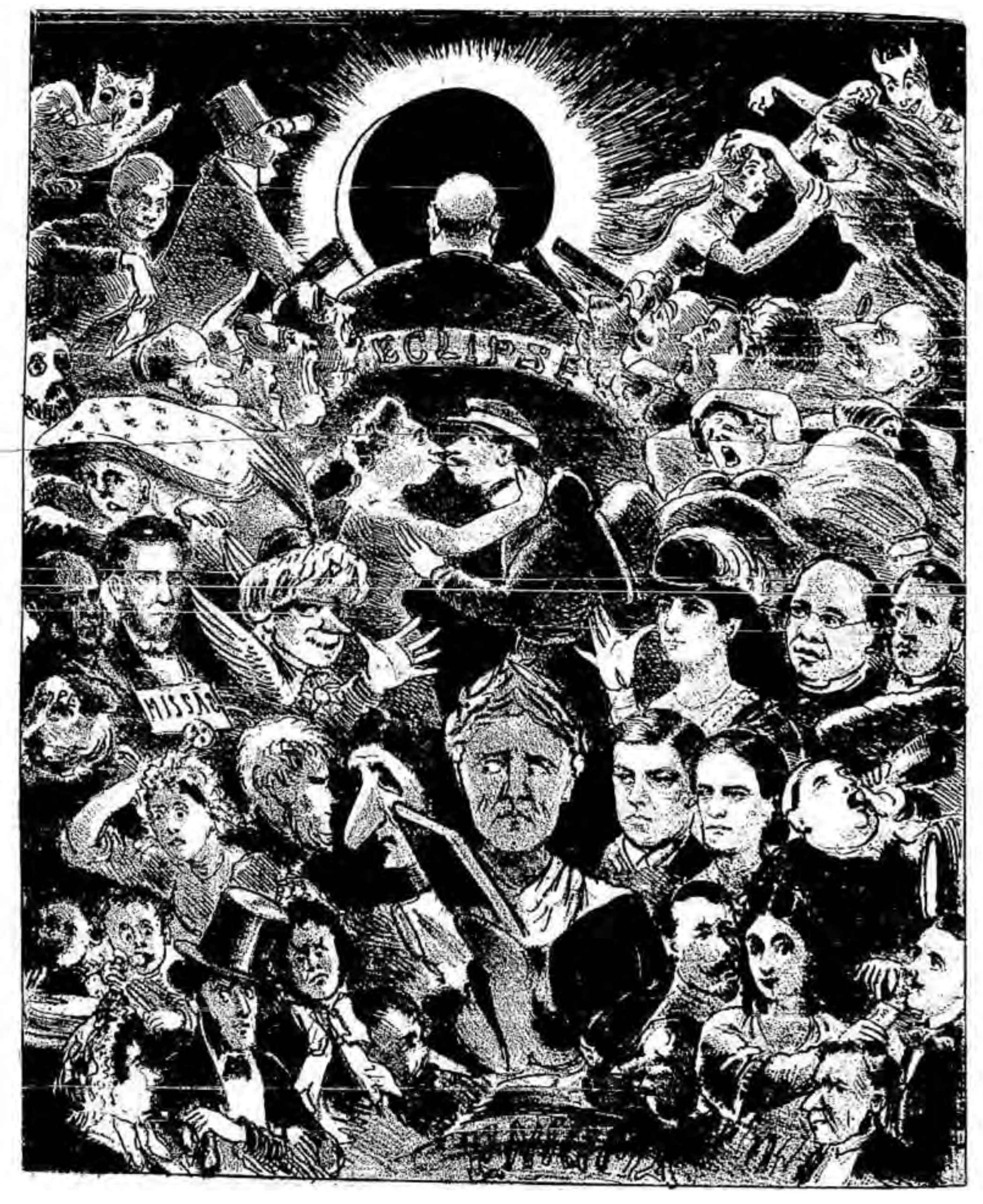




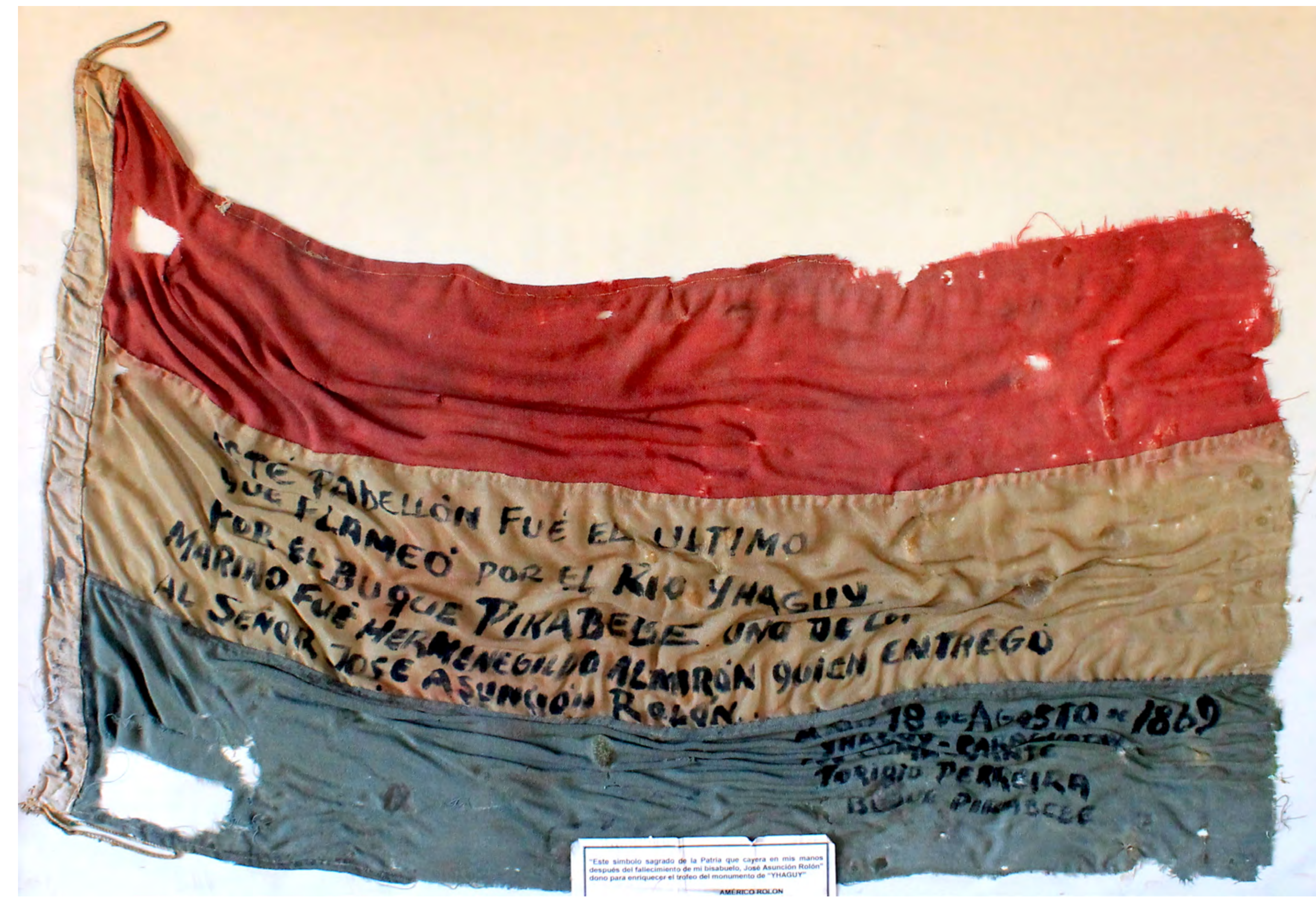




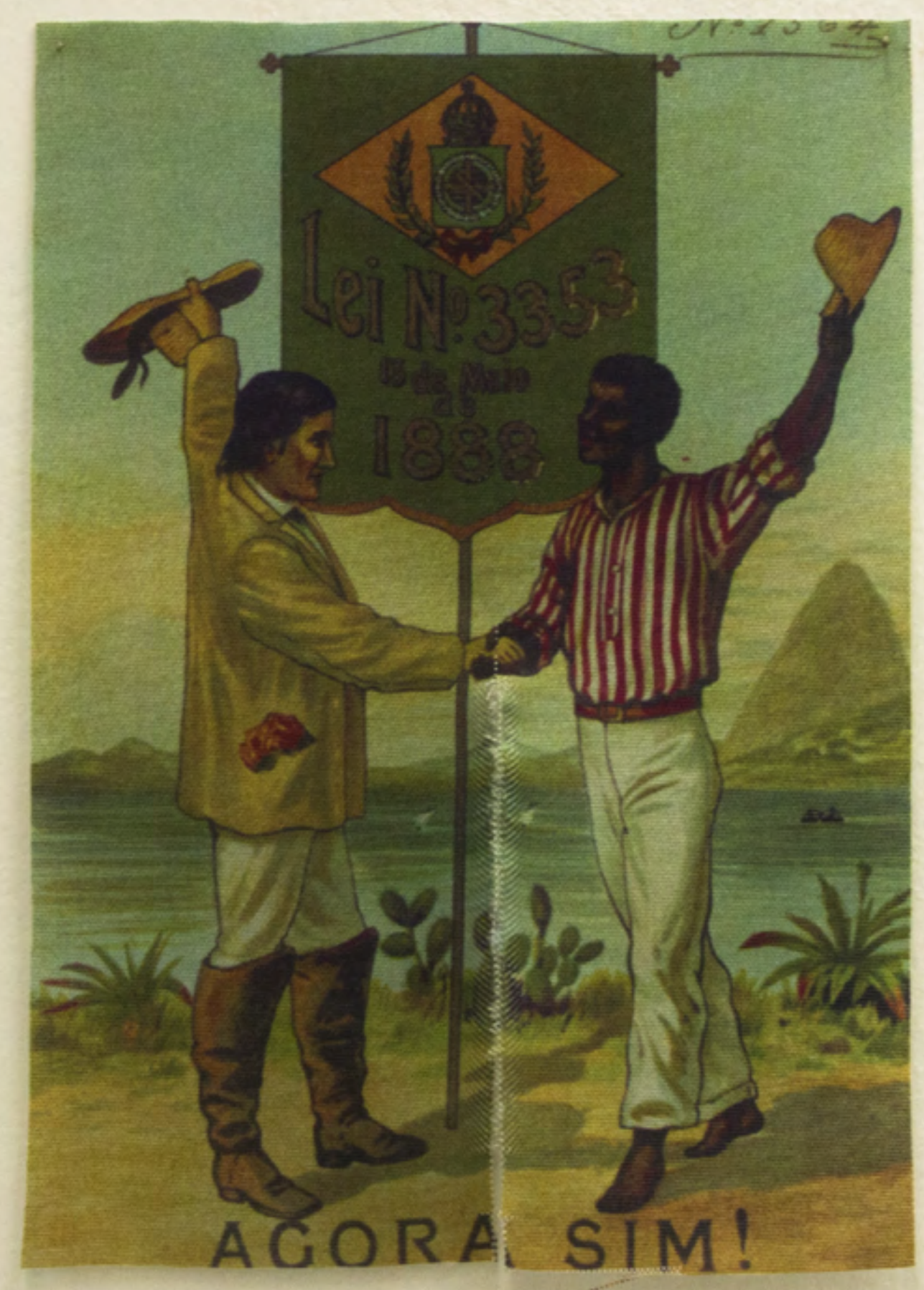



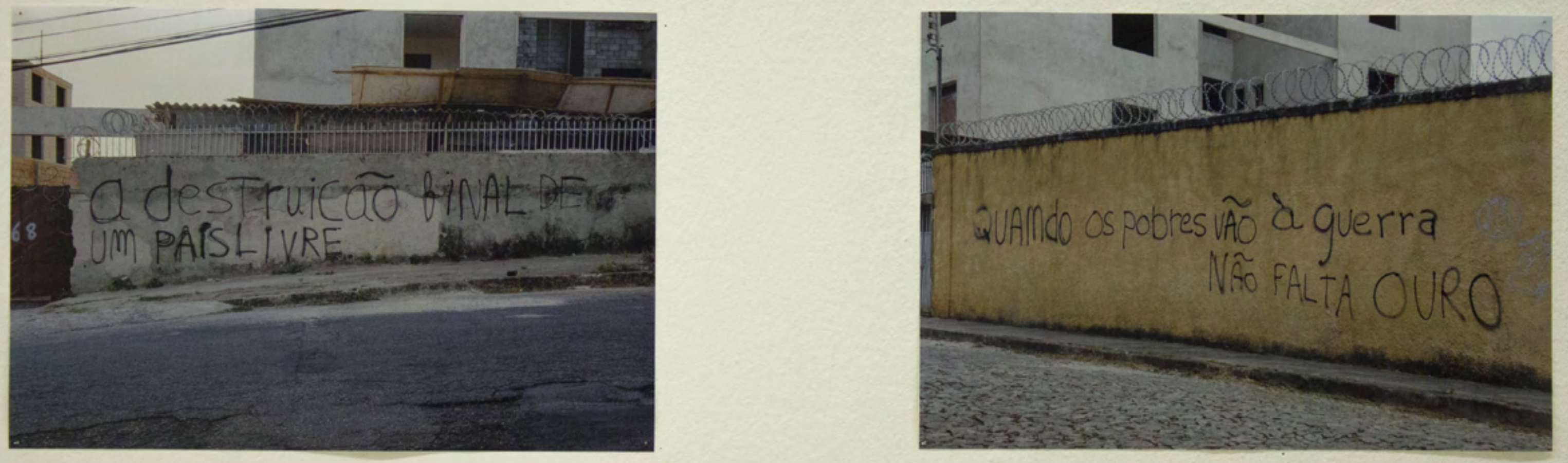


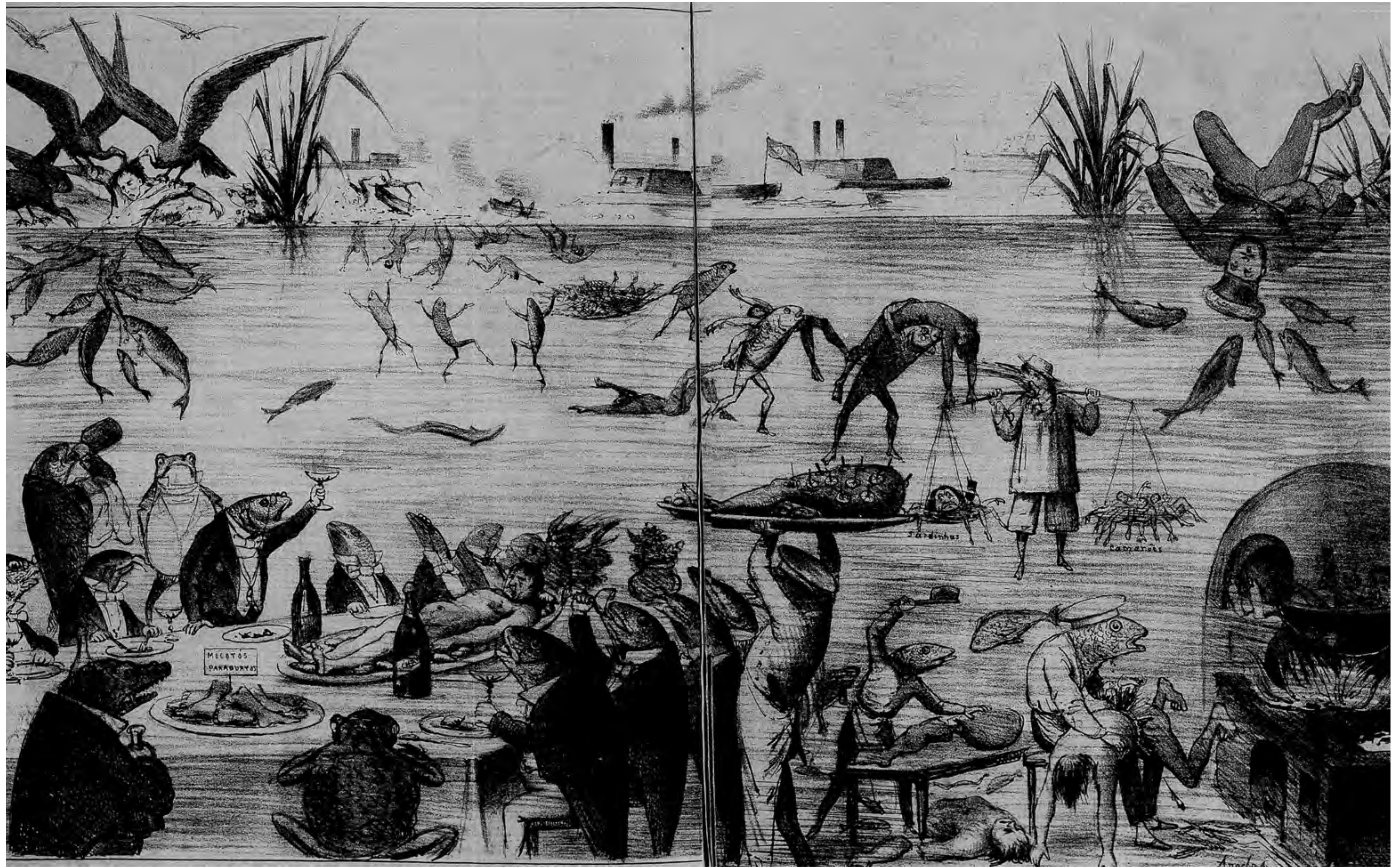




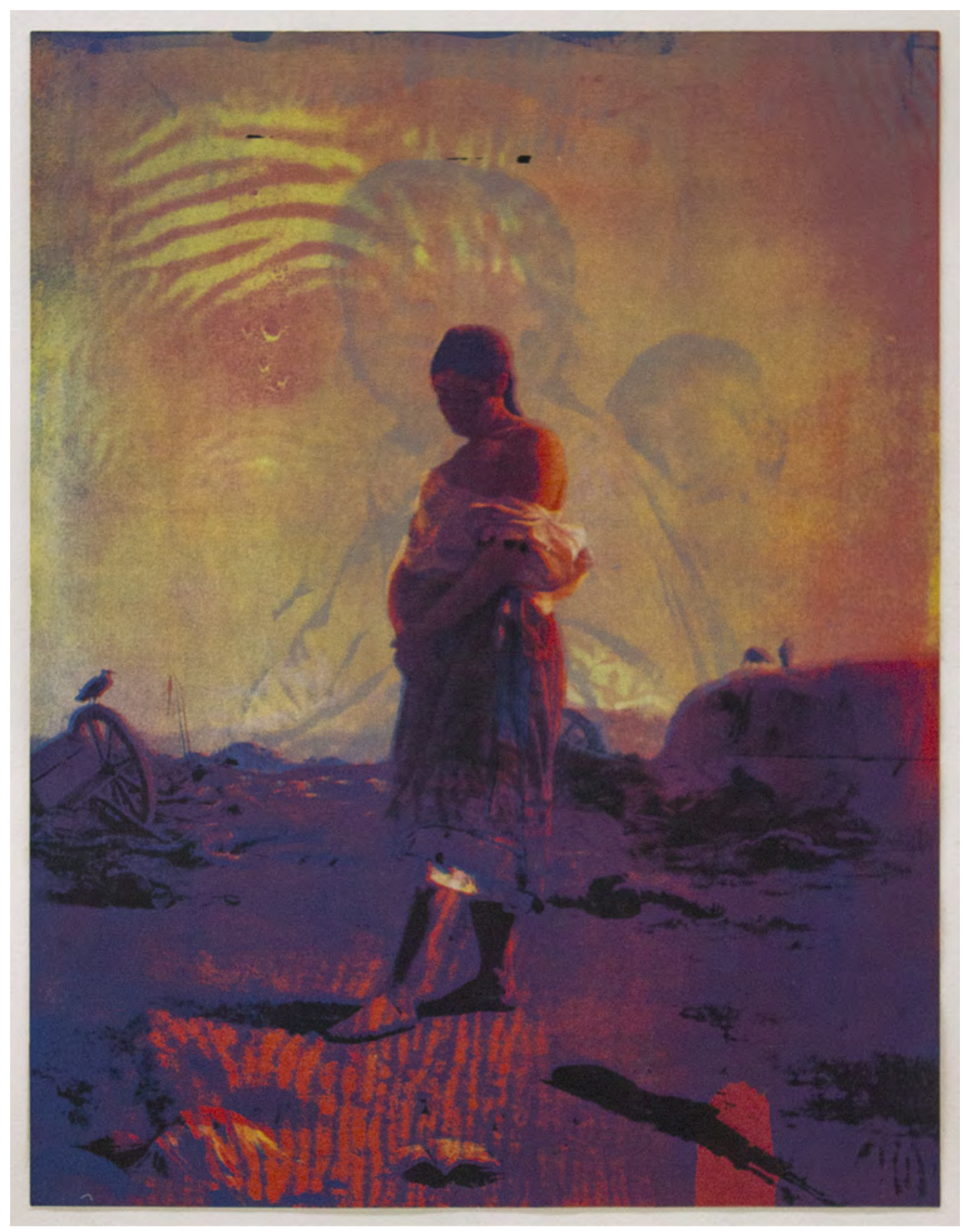




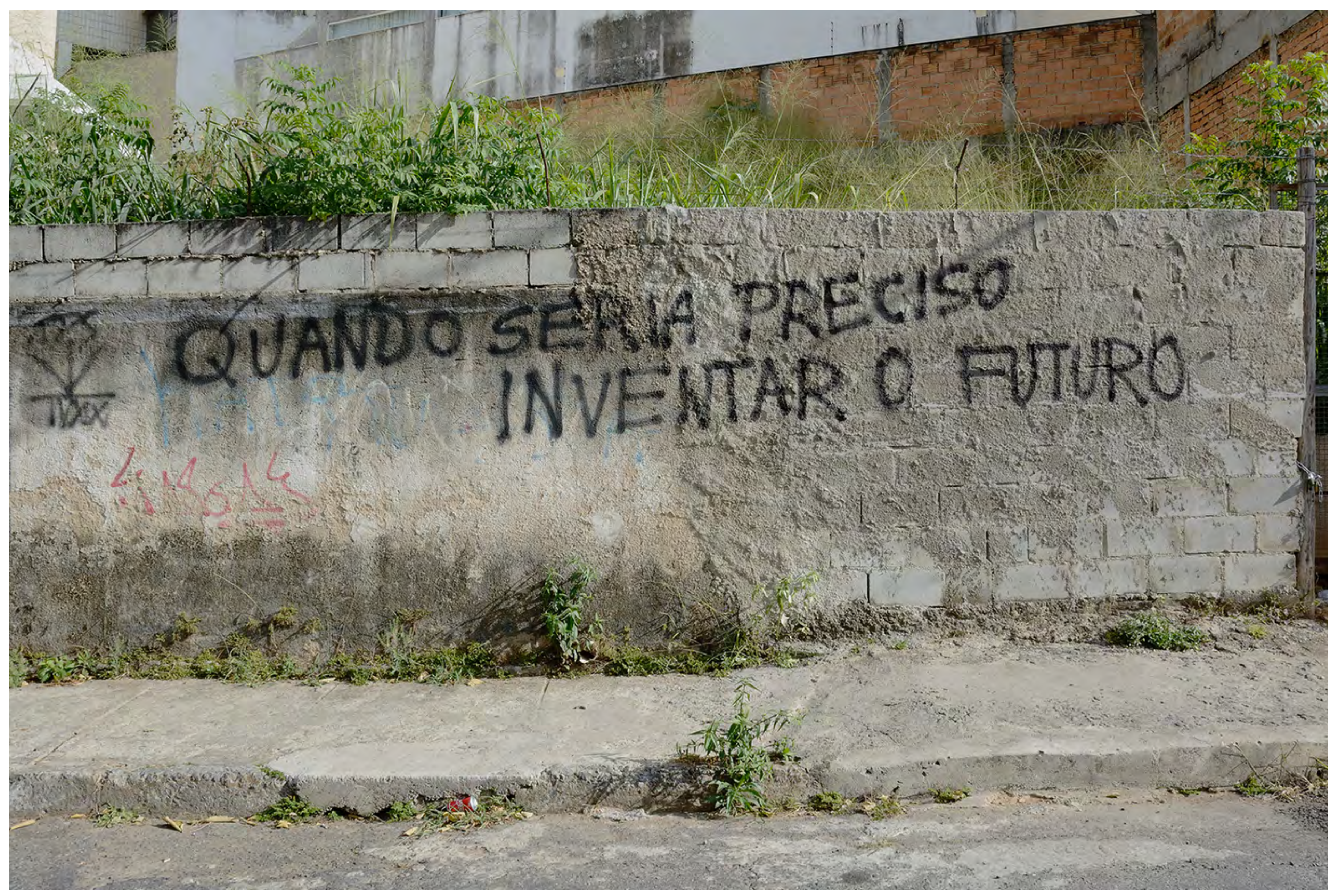

